\title{
Kelola
}

Jurnal Manajemen Pendidikan

Magister Manajemen Pendidikan

ISSN 2443-0544

FKIP Universitas Kristen Satya Wacana

Volume: 3, No. 1, Januari-Juni 2016

jurnalkelola@gmail.com

Halaman: 1-14

\section{EVALUASI PROGRAM AKSELERASI DI SMP NEGERI KOTA AMBON}

\author{
David Tuhurima \\ Universitas Patimura Ambon \\ nyongseram@yahoo.co.id
}

\begin{abstract}
This research is aimed to evaluate acceleration program in SMP Negeri 6 Ambon which is include four components such as: (1) Context (2) Input (3) Process, and (4) Product. This is an evaluative research using descriptive analysis. This research informants are principals, viceprincipals, program coordinators, teachers, school committees, parents, and students accelerated program. Research sites in SMP Negeri 6 Ambon. The data is collected using interview, observation and documentation study techniques. For the data validation, this research used triangulation of sources and techniques. The results shows that, from context, the implementation of the acceleration program is a school's initiative as an effort to address the needs and provide the education services for special smart learners (IQ $\geq 130$ ) as well as the effectiveness of school facilities and infrastructure utilization. From the point of input including: (a) the program policy, the school has permission from the department as the juridical basis for accelerated program implementation, and (b) planning program: recruitment of learners are in accordance with the criteria, curriculum acceleration program already differentiated, educators (teachers) already meets the qualifications and criteria as teacher in class acceleration, infrastructure and financing program is sufficient to support the accelerated program. In terms of Process, acceleration program in SMP Negeri 6 Ambon has been implemented in accordance with the planning program, although there are still some shortcomings and obstacles. Recruitment of learners already implemented, curriculum adjustments will only be visible on the implementation of the teaching and learning activities, educators (teachers) are still there who do not meet the qualifications and criteria as a teacher in class acceleration, infrastructure is not sufficient to support an accelerated program of activities, and financing programs that is still lacking. The implementation of the teaching and learning process in an accelerated program carried out on a daily basis according to the effective education calendar prepared by the school. The obstacles in the implementation of the accelerated program associated with government policy on the closure of the accelerated program. Product of the implementation of an accelerated program at SMP Negeri 6 Ambon that learners can complete their education exactly two years, passed $100 \%$, and is accepted in favorite high school, both public and private.

Thus, the implementation of accelerated program at SMP Negeri 6 Ambon should be continued but with improvements. For the further service, the school is suggested to improve the service toward accelerated program learners with providing the needs related to the implementation of the program, and for the education department, related to the monitoring, supervision, and evaluation toward the implementation of accelerated program, especially in SMP Negeri 6 Ambon.
\end{abstract}

Keywords: Accelerated Program, Evaluation Program, CIPP Model. 


\section{PENDAHULUAN}

Akselerasi atau percepatan belajar merupakan salah satu penanganan pendidikan yang memberikan kesempatan kepada siswa untuk belajar dengan kecepatan yang lebih tinggi dari ratarata anak seusianya atau belajar pada usia yang lebih muda dari umumnya dengan stimulasi belajar yang disesuaikan dengan kecepatan belajar siswa (Colangelo, 1991; Feldhusen, 1995; Pressey, 1949 dalam Winanti dkk, 2007). Hal ini berarti siswa yang memiliki kecerdasan yang sangat tinggi dapat mempelajari berbagai topik yang seharusnya diberikan kepada siswa di kelas yang lebih tinggi. Jadi akselerasi lebih berfokus pada kecepatan dalam belajar, bukan pada kedalaman ataupun keluasan dalam belajar.

Dalam program percepatan belajar untuk SD, SLTP, dan SMU yang dicanangkan oleh pemerintah pada tahun 2000, akselerasi didefinisikan sebagai salah satu bentuk pelayanan pendidikan yang diberikan bagi siswa dengan kecerdasan dan kemampuan luar biasa untuk dapat menyelesaikan pendidikan lebih awal dari waktu yang telah ditentukan, sehingga mereka dapat menyelesaikan pendidikan formalnya dalam waktu yang lebih singkat atau pada usia yang lebih muda (Direktorat PSLB, 2010).

Program akselerasi di Indonesia telah dilaksanakan mulai tahun 2002 di beberapa sekolah. Namun, dalam implementasinya, menurut Dwi Astutik (2012) program akselerasi yang selama ini berjalan hanyalah sebuah praktek komodifikasi dalam dunia pendidikan. Praktek komodifikasi yang selama ini selalu dianggap wajar sebagai uang sumbangan suka rela kepada sekolah cenderung mendorong masyarakat untuk melakukan persaingan secara terbuka untuk memasukkan anak dalam kelas akselerasi. Keadaan demikian mendorong akselerasi dalam implementasinya tidak berjalan sesuai dengan tujuan dan sasaran.

Permasalahan tersebut diatas diperkuat dengan hasil penelitian yang dilakukan oleh Hawadi dkk (1998 dalam Haryanto dan Pujaningsih, 2008) pada 20 SMA unggulan di 16 provinsi, menyimpulkan bahwa: implementasi pelayanan pendidikan khusus bagi anak berbakat intelektual di sekolah mengalami beberapa hambatan, antara lain: Pertama, program akselerasi yang merupakan salah satu cara pelayanan anak berbakat intelektual ternyata tidak tepat sasaran. Program percepatan belajar (akselerasi) tidak cukup memberikan dampak positif pada siswa berbakat untuk mengembangkan potensi intelektualnya yang tinggi karena jumlah siswa yang tergolong memiliki potensi kecerdasan dan bakat istimewa hanya 9,7\%. Dari temuan tersebut berarti sebagian besar siswa $(92,3 \%)$ yang mengikuti program akselerasi bukan merupakan anak 
berbakat intelektual tinggi. Kedua, tidak semua sekolah disiapkan untuk melayani anak berbakat intelektual. guru yang mengajar pada program akselerasi saja tidak disiapkan untuk mengajar siswa berbakat intelektual. Ketiga, tidak semua sekolah memahami prosedur identifikasi anak berbakat intelektual. Menurut Sri Utari (2014), hasil survey yang dilakukan pada tahun 2010 terhadap sekolah unggulan di Kota Yogyakarta menunjukkan tidak semua siswa di kelas Cerdas Istimewa (CI) adalah siswa CI (berdasarkan tes psikologi), tidak ada seleksi khusus guru CI, dan diferensiasi kurikulum masih sebatas diferensiasi waktu. Keadaan tersebut cukup memberikan gambaran bahwa siswa yang memiliki potensi kecerdasan dan bakat istimewa memerlukan perhatian yang serius.

Suchman (1961 dalam Arikunto dan Safruddin, 2014) memandang evaluasi sebagai sebuah proses menentukan hasil yang telah dicapai beberapa kegiatan yang direncanakan untuk mendukung tercapainya tujuan. Definisi lain dikemukakan oleh Worthen dan Sanders (1973 dalam Arikunto dan Safruddin, 2014), kedua ahli tersebut mengatakan bahwa evaluasi adalah kegiatan mencari sesuatu yang berharga tentang sesuatu; dalam mencari sesuatu tersebut juga termasuk mencari informasi yang bermanfaat dalam menilai keberadaan suatu program, produksi, prosedur, serta alternatif strategi yang diajukan untuk mencapai tujuan yang sudah ditentukan. Stufflebeam (1971 dalam Arikunto dan Safruddin, 2014) mengatakan bahwa evaluasi merupakan penggambaran, pencarian, dan pemberian informasi yang sangat bermanfaat bagi pengambil keputusan dalam menentukan alternatif keputusan.

Menurut Ira Mendasari (2013) dalam penelitiannya tentang studi evaluasi efektivitas program akselerasi menemukan bahwa program akselerasi SMP Negeri 1 Argamakmur berada pada posisi efektif karena program akselerasi ini sudah sesuai dengan kriteria yang terdapat dalam pedoman penyelenggaraan pendidikan untuk peserta didik cerdas istimewa dari Depdiknas Direktorat PSLB Tahun 2009. Hasil penelitian tersebut dikuatkan oleh penelitian Citra Ceria (2011), dengan judul "Evaluasi Pelaksanaan Program Akselerasi di SMA Negeri 1 Banjarmasin”, menemukan bahwa: (1) Animo masyarakat cukup tinggi terhadap program akselerasi dan dalam hal partisipasi pun sudah cukup baik; (2) Dari segi input, kompetensi guru sudah sesuai dengan kriteria yang diinginkan dan telah mencapai $87,5 \%$. Dari segi karakteristik siswa, yang diterima pada program ini telah mencapai $85,7 \%$ sesuai standar yang berlaku. Untuk sarana dan prasarana kelas program akselerasi sudah memenuhi pencapaian yang sangat baik yaitu 100\%. Kurikulum yang digunakan untuk program akselerasi ini adalah kurikulum nasional yaitu Kurikulum Tingkat Satuan Pendidikan (KTSP) yang dikembangkan sesuai dengan karakteristik siswa yang memiliki 


\section{Jurnal Kelola, Vol. 3, No. 1, Januari-Juni 2016}

kemampuan dan kecerdasan luar biasa. (3) Dari segi proses, Proses Belajar Mengajar (aktivitas guru dan siswa) sudah menunjukkan hal yang baik dengan pencapaian 100\%. Untuk strategi pembelajaran pun sudah mencapai 100\%. Namun untuk pengelolaan program hanya mencapai 50\% karena tidak adanya Job Description untuk masing-masing anggota pengurus program. (4) Dari segi produk, prestasi akademik menunjukkan hasil yang sangat baik karena setiap tahunnya selalu menghasilkan 100\% kelulusan dengan nilai rata-rata di atas standar. Namun dari segi prestasi non akademik baru mencapai 33,3\% karena siswa program ini hanya sedikit yang mengikuti lombalomba ekstrakurikuler.

Hasil penelitian di atas memberikan gambaran bahwa penyelenggaraan program akselerasi belum sepenuhnya dilaksanakan dengan baik. Dengan demikian, kegiatan evaluasi sangat penting dilaksanakan dalam rangka perbaikan dan peningkatan kualitas layanan penyelenggaraan program akselerasi.

Berdasarkan permasalahan di atas, maka rumusan masalah dalam penelitian ini adalah: bagaimana context, input, process, dan product program akselerasi di SMP Negeri 6 Ambon?. Sedangkan, tujuannya adalah untuk mengevaluasi context, input, process, dan product program kelas akselerasi di SMP Negeri 6 Ambon. Hasil penelitian ini diharapkan dapat dijadikan bahan referensi mengenai evaluasi program akselerasi, dan dapat digunakan oleh sekolah sebagai data ilmiah dalam membuat keputusan untuk perbaikan program di masa datang, serta dapat berguna sebagai saran untuk perbaikan dalam implementasi kebijakan pendidikan yang dilakukan oleh Dinas Pendidikan.

\section{METODE PENELITIAN}

Penelitian ini merupakan penelitian evaluasi dengan menggunakan pendekatan deskriptif. Model evaluasi yang digunakan dalam penelitian ini adalah model CIPP. Penelitian dilakukan di SMP Negeri 6 Ambon. Subjek dalam penelitian ini adalah kepala sekolah, wakil kepala sekolah, koordinator program akselerasi, petugas tata usaha, guru, siswa akselerasi, komite sekolah, dan orang tua. Teknik pengumpulan data dengan wawancara, observasi, dan studi dokumentasi. Teknik analisa data yang dilakukan dalam penelitian ini yaitu teknik analisa data kualitatif yang dideskripsikan dengan reduksi data, display data, dan kesimpulan/verifikasi data. Uji keabsahan data dengan triangulasi sumber dan teknik.

\section{HASIL PENELITIAN DAN PEMBAHASAN}

\section{Evaluasi Context Program Akselerasi SMP Negeri 6 Ambon}


Latar belakang dilaksanakannya program ini adalah pemahaman bahwa siswa yang memiliki bakat akademik luar biasa pada dasarnya dapat menguasai pelajaran lebih cepat daripada siswa pada umumnya. Temuan penelitian menunjukkan bahwa penyelenggaraan program akselerasi di SMP Negeri 6 Ambon merupakan inisiatif sekolah. Hal ini merupakan implementasi dari Undang-Undang RI Nomor 20 Tahun 2003 Bab IV pasal 5 tentang Sistem Pendidikan Nasional yang mengamanatkan bahwa "warga negara yang memiliki potensi kecerdasan dan bakat istimewa berhak memperoleh pendidikan layanan khusus".

Penyelenggaraan program akselerasi di SMP Negeri 6 Ambon bertujuan untuk menjawab kebutuhan dan memberikan pelayanan kepada peserta didik cerdas istimewa (IQ $\geq 130$ ), serta untuk mengefektifkan penggunaan sarana dan prasarana yang telah ada karena sebelum menyelenggarakan program akselerasi, SMP Negeri 6 Ambon juga sudah menyelenggarakan program Moving Class. Kondisi tersebut sesuai dengan yang tercantum dalam Depdiknas (2009) bahwa penyelenggaraan program akselerasi mempunyai maksud dan tujuan untuk memberikan kesempatan bagi peserta didik cerdas istimewa untuk mengikuti pendidikan sesuai dengan potensi kecerdasan yang dimilikinya. Selain itu juga, adanya dukungan yang sangat baik dari masyarakat terhadap penyelenggaraan program akselerasi. Dimana, program tersebut juga merupakan upaya sekolah untuk menjawab kebutuhan masyarakat dalam hal pemberian pelayanan pendidikan kepada peserta didik yang memiliki potensi kecerdasan dan bakat istimewa. Temuan penelitian ini senada dengan yang diungkapkan oleh Widiastono (2004) yang menyatakan bahwa dukungan stakeholders (masyarakat/komite/warga sekolah/dan praktisi pendidikan) akan memberikan pertimbangan dalam penentuan pelaksanaan kebijakan pendidikan akselerasi di sekolah. Partisipasi stakeholders diharapkan dengan suka rela memberikan perhatian, pengorbanan, dan kerja sama untuk meningkatkan kualitas penyelenggaraan program akselerasi pendidikan.

\section{Evaluasi Input Program Akselerasi SMP Negeri 6 Ambon}

SMP Negeri 6 Ambon memiliki kapasitas dan status selaku Sekolah Standar Nasional terbaik di Provinsi Maluku, menyelenggarakan program kelas akselerasi sebagai implementasi kebijakan program pendidikan perihal pemenuhan kebutuhan pendidikan bagi peserta didik cerdas istimewa. Dalam penyelenggaraannya, sekolah berpedoman pada Surat Keputusan Direktur Pembinaan Pendidikan Khusus dan Layanan Khusus Pendidikan Dasar Direktorat Jenderal Pendidikan Dasar Kementerian Pendidikan dan Kebudayaan Nomor: 1033/C4/KU/2014 tentang pemberian bantuan sosial operasional PK LK, inklusi, CI BI, Braille, dan UKS/ruang terapi pendidikan dasar tahun 2014. 


\section{Jurnal Kelola, Vol. 3, No. 1, Januari-Juni 2016}

Perencanaan program akselerasi SMP Negeri 6 Ambon dilakukan terhadap komponenkomponen program akselerasi yang saling berhubungan dalam menunjang kelancaran penyelenggaraannya, yaitu: (1) Rekrutmen peserta didik: temuan penelitian menunjukkan bahwa proses rekrutmen peserta didik program akselerasi dimulai pada saat penerimaan peserta didik baru. Selanjutnya, melakukan seleksi administrasi, tes akademis, dan tes psikologis. Sebagaimana teori Renzulli \& Reis (Solangelo dalam Semiawan, 2007) bahwa prosedur identifikasi anak berbakat dalam Model Pengayaan Sekolah (Schoolwide Enrichment Model - SEM) terdiri dari enam langkah yaitu: nominasi berdasarkan tes, nominasi guru, alternatif lainnya yang bisa merupakan nominasi teman sebaya, nominasi orang tua atau nominasi diri, maupun tes kreativitas, nominasi khusus yang merupakan review terakhir dari mereka yang sebelumnya tidak terlibat dalam nominasi-nominasi tersebut, nominasi informasi tindakan (action information), serta proses nominasi sebagaimana dilakukan oleh guru berdasarkan pesan informasi tindakan (PIT); (2) Kurikulum program akselerasi: perencanaan kurikulum yang dilakukan pada program akselerasi SMP Negeri 6 Ambon berdasarkan hasil temuan penelitian sudah memenuhi ketentuan yang ada, yaitu kurikulum KTSP yang di diferensiasi. Hasil temuan penelitian ini didukung oleh pernyataan dari Mukhtar dkk (2007) menyatakan bahwa kurikulum yang dipergunakan dalam program akselerasi adalah kurikulum nasional yang sudah distandarisasi, namun hendaknya diimprovisasi alokasi waktunya sesuai dengan tuntutan belajar siswa yang memiliki kemampuan dan kecerdasan, serta motivasi belajar yang lebih tinggi; (3) Tenaga pendidik (guru): temuan penelitian menunjukkan bahwa dalam memilih guru yang mengajar di program akselerasi ditentukan oleh kepala sekolah sesuai dengan kriteria bagi guru program akselerasi. Hal tersebut didukung oleh pernyataan Marland (1972) yang menyatakan bahwa tenaga pendidik akselerasi harus mempunyai keunggulan tertentu, baik dari segi penguasaan materi pelajaran, metode pengajaran, maupun komitmen dalam melaksanakan tugas, karena para siswa yang mereka hadapi adalah mereka yang memiliki kemampuan dan kecerdasan yang luar biasa; (4) Sarana dan prasarana: fasilitas yang disediakan pihak sekolah sudah cukup memadai dan memenuhi ketentuan yang ada untuk penyelenggaraan program akselerasi di SMP Negeri 6 Ambon. Lingkungan belajar di kelas akselerasi seperti ini juga memenuhi kaidah yang disampaikan oleh Mujiman (2006), agar kegiatan belajar dapat berlangsung efektif, di setiap lingkungan perlu penyediaan sumber informasi, narasumber, dan adanya suasana yang kondusif bagi berlangsungnya kegiatan belajar. Dengan adanya sarana dan prasarana yang memadai, maka akan mampu mendukung dalam penyelenggaraan program akselerasi; (5) Pembiayaan: pembiayaan untuk penyelenggaraan program akselerasi bersumber dari pemerintah (dana BOS) dan sumbangan berupa iuran tetap dari orang tua peserta didik setiap bulan. Hal ini selaras dengan pendapat Levin (1987 dalam 
Fattah, 2008), pembiayaan sekolah adalah proses dimana pendapatan dan sumberdaya tersedia digunakan untuk memformulasikan dan mengoperasionalkan sekolah di berbagai wilayah geografis dan tingkat pendidikan yang berbeda-beda. Setiap kebijakan dalam pembiayaan sekolah akan mempengaruhi bagaimana sumber daya diperoleh dan dialokasikan.

\section{Evaluasi Process Program Akselerasi di SMP Negeri 6 Ambon}

Penyelenggaraan program akselerasi di SMP Negeri 6 Ambon diawali dengan persiapan penyelenggaraan program. Pihak sekolah menyiapkan berbagai sumber daya program yang mendukung terselenggaranya program akselerasi, meliputi: kesiapan guru yang memenuhi syarat rata-rata pendidikannya lulusan S1, sarana dan prasarana belajar yang memadai, dan lain sebagainya. Langkah selanjutnya sekolah membuat rencana program akselerasi disusun dengan baik dalam bentuk proposal yang memuat profil sekolah dan diajukan kepada dinas pendidikan kota, provinsi, dan pemerintah pusat dengan tujuan mendapatkan izin penyelenggaraan program akselerasi.

Mekanisme penyelenggaraan program akselerasi di SMP Negeri 6 Ambon mengikuti alur sebagai berikut: (1) sekolah menyusun proposal permohonan penyelenggaraan kepada Dinas Pendidikan Kota, Dinas Pendidikan Provinsi, dan Direktorat PLB yang dilengkapi dengan profil sekolah, (2) Dinas Pendidikan Kota melakukan observasi dan supervisi ke sekolah, (3) hasil observasi dan supervisi itu menjadi dasar rekomendasi ke Dinas Provinsi, (4) Dinas Provinsi melakukan observasi dan supervisi ke sekolah, dan (5) Dinas Provinsi menerbitkan SK Penetapan sebagai sekolah penyelenggara program akselerasi.

Ditinjau dari bentuk penyelenggaraannya, program akselerasi di SMP Negeri 6 Ambon menggunakan model "Kelas Khusus", yaitu: peserta didik yang memiliki potensi kecerdasan dan bakat istimewa belajar dalam kelas khusus. Dalam artian bahwa ruang belajar untuk kelas akselerasi di SMP Negeri 6 Ambon disendirikan. Hal ini senada dengan yang diungkapkan oleh Widiastono (2004) yang menyatakan bahwa model kelas khusus akselerasi adalah kelas yang dibuat untuk kelompok peserta didik yang memiliki potensi kecerdasan istimewa dalam satuan pendidikan reguler pada jenjang dasar dan menengah tanpa membaur dengan peserta didik reguler lainnya. Pernyataan tersebut diperkuat oleh Mukhtar dkk (2007), pembinaan siswa-siswa yang memiliki kemampuan dan kecerdasan luar biasa secara kolektif (kelompok) diberi kesempatan secara khusus sesuai dengan potensi yang mereka miliki ke dalam kelas khusus. 


\section{Jurnal Kelola, Vol. 3, No. 1, Januari-Juni 2016}

Untuk mengoptimalkan penyelenggaraan program akselerasi di SMP Negeri 6 Ambon, maka kepala sekolah telah membentuk tim penyelenggara program akselerasi. Temuan penelitian menunjukkan bahwa pengelolaan program akselerasi tidak dirangkap oleh kepala sekolah. Artinya, kepala sekolah berdasarkan mekanisme yang ada, telah menetapkan ketua koordinator program akselerasi tersendiri, dengan tugas utama mengelola program akselerasi. Hal tersebut sesuai dengan pendapat Argyris (1978) yang menyatakan bahwa struktur organisasi merupakan seperangkat hubungan yang efektif antara orang-orang dalam organisasi yang dibentuk untuk melaksanakan tugas-tugas tertentu, dalam kondisi lingkungan tertentu guna mencapai tujuan atau sasaran tertentu. Menurut Nawawi (1996), penempatan personel pada unit kerja dan posisi yang tepat sesuai dengan kemampuan pendidikan dan pengalamannya memiliki pengaruh yang kuat terhadap pencapaian keberhasilan tujuan suatu organisasi.

Pelaksanaan merupakan bentuk konkrit dari apa yang telah direncanakan sebelumnya, meliputi: (1) Rekrutmen peserta didik: penerimaan peserta didik baru setiap tahun ajaran baru, yang dimulai pada bulan Juni. Berdasarkan perencanaan, tiap kelas ditempati oleh 20 orang peserta didik. Namun, dalam pelaksanaannya, jumlah peserta didik yang mengikuti program akselerasi setiap tahun rata-rata berjumlah 25 orang peserta didik. Pelaksanaan seleksi peserta didik sudah dilakukan sesuai dengan yang direncanakan, yaitu dengan melakukan tiga tahapan, tes potensial akademik, psikotes, dan kesehatan. Proses seleksi untuk menjadi peserta didik kelas akselerasi dilakukan secara objektif, akuntabel (dapat dipercaya), dan transparan, Hal tersebut sesuai dengan pendapat Widiastono (2004) yang menyatakan bahwa masukan (input, intake) siswa di seleksi secara ketat dengan menggunakan kriteria tertentu dan prosedur yang dapat dipertanggung-jawabkan; (2) Kurikulum: kurikulum kelas akselerasi pada dasarnya sama dengan kurikulum kelas reguler, yaitu Kurikulum Tingkat Satuan Pendidikan (KTSP) dan muatan lokal, perbedaannya kurikulum tersebut dalam pengembangannya harus dideferensiasikan untuk memenuhi kebutuhan pendidikan peserta didik yang memiliki potensi kecerdasan dan bakat istimewa. Sehingga, lama waktu belajar di SMP untuk kelas akselerasi selama dua tahun sedangkan bagi kelas reguler adalah tiga tahun. Temuan penelitian ini didukung oleh pernyataan dari Ward (1980) yang menyatakan bahwa sekolah penyelenggara pendidikan akselerasi bagi peserta didik yang memiliki kemampuan istimewa dan bakat istimewa (giftend and talented) harus berhadapan dengan tuntutan proses pengembangan kurikulum diferensiasi; (3) rekrutmen dan pembinaan tenaga pendidik (guru): tidak dijumpai adanya penerapan seleksi secara khusus yang dilakukan oleh pihak sekolah dalam memilih guru yang mengajar pada kelas akselerasi. Pemilihan guru program akselerasi sepenuhnya ditentukan oleh kepala sekolah dengan pertimbangan, antara lain: 
guru yang sudah senior, memenuhi standar kompetensi, dan mengajar sesuai dengan latar belakang pendidikan. Hal ini selaras dengan Direktorat PSLB (2010) bahwa pendidikan khusus yang diselenggarakan bagi siswa CI hendaknya dirancang sesuai dengan kebutuhan siswa dan diampu oleh guru yang kompeten. Selanjutnya, Guru-guru yang di rekrut untuk program akselerasi di SMP Negeri 6 Ambon diharuskan untuk mengikuti diklat dan workshop. Hal ini dilakukan dalam rangka untuk meningkatkan kompetensi dan kualitas mengajar guru sehingga mampu memberikan pelayanan pendidikan kepada peserta didik yang memiliki kemampuan dan kecerdasan luar biasa. Hal ini selaras dengan pendapat yang dikemukakan oleh Lubis (dalam Rena Putri, 2005) bahwa guru yang mengajar program akselerasi adalah guru-guru biasa yang juga mengajar program reguler, hanya saja sebelumnya guru-guru tersebut telah dipersiapkan dalam suatu lokakarya dan workshop sehingga memiliki pemahaman dan ketrampilan untuk memberikan pengajaran bagi siswa akselerasi; (4) ketersediaan sarana dan prasarana: sarana dan prasarana di SMP Negeri 6 Ambon yang disediakan untuk peserta didik akselerasi pada dasarnya tidak berbeda jauh dengan peserta didik reguler. Sarana dan prasarana yang dimiliki SMP Negeri 6 Ambon sudah cukup lengkap dan memadai, hanya saja jumlah ruangannya terbatas, misalnya laboratorium. Saat ini kondisi sarana dan prasarana dalam kondisi baik. Ruang kelas akselerasi juga sudah cukup nyaman karena sudah dilengkapi dengan berbagai fasilitas yang tidak dimiliki oleh kelas reguler. Hal tersebut sebagaimana yang diungkapkan oleh Hawadi (2004) bahwa sarana dan prasarana program akselerasi hampir sama dengan program reguler, tetapi kualitasnya lebih ditingkatkan; (5) pembiayaan program: pembiayaan untuk program akselerasi di SMP Negeri 6 Ambon sampai saat ini masih menjadi permasalahan karena subsidi dari pemerintah masih belum mencukupi. Sumber dana untuk program akselerasi berasal dari Pemerintah Pusat yaitu berupa dana BOS dan orang tua peserta didik. Berkaitan dengan sumber biaya pendidikan, Nicholas Barr (2005) menyatakan "If it is not possible to rely wholly on public funding, it is necessary to bring in private finance-but in ways that do not deter students from poor backgrounds". Artinya jika tidak memungkinkan menggantungkan sepenuhnya pada subsidi pemerintah, diperlukan kemampuan dalam menyerap dana masyarakat (SPP), akan tetapi jangan sampai membebani peserta didik dari latar belakang keluarga yang tidak mampu. Sumber pendanaan sudah sesuai dengan Undang-Undang Nomor 20 Tahun 2003 pasal 46 ayat 1 dan Peraturan Pemerintah Nomor 48 Tahun 2008 pasal 2 bahwa pendanaan pendidikan menjadi tanggung jawab bersama antara pemerintah pusat, pemerintah daerah, dan masyarakat.

Kegiatan pembelajaran program akselerasi secara umum telah diatur dalam kalender pendidikan program akselerasi SMP Negeri 6 Ambon. Bentuk kegiatan pembelajaran di kelas 


\section{Jurnal Kelola, Vol. 3, No. 1, Januari-Juni 2016}

akselerasi menggunakan kurikulum KTSP dengan pendekatan dan strategi pembelajaran yang dikemas sedemikian rupa sehingga materi yang mestinya diberikan dalam waktu enam bulan harus dapat diselesaikan dalam waktu empat bulan per semester. Kunci keberhasilan guru dalam memberikan pengajaran di program akselerasi terletak pada kemampuan guru untuk melakukan analisis materi pelajaran dengan kalender pendidikan. Temuan ini sejalan dengan pendapat beberapa orang pakar diantaranya menurut Meier (2000) menyatakan bahwa untuk mendesain pembelajaran percepatan harus memperhatikan prinsip aktivitas, artinya para peserta didik belajar banyak dari pengalaman aktif dibandingkan apabila mereka mempelajari dari presentasi. Kemudian menurut Mukhtar dkk (2007) menyatakan bahwa pembelajaran akselerasi bersifat responsif terhadap perubahan dan berupaya menciptakan program pembelajaran yang fleksibel dan bertujuan untuk mengadakan perbaikan secara kontinu. Sedangkan menurut Colin (1997) dengan metode percepatan belajar ini seorang siswa dapat belajar secara menyenangkan, dan mereka dapat menciptakan suatu pembelajaran yang sukses dan menyenangkan.

SMP Negeri 6 Ambon sebagai sekolah penyelenggara program akselerasi, memiliki tantangan dalam menyelenggarakan program akselerasi kedepan, karena adanya kebijakan pemerintah tentang penutupan program akselerasi. Kalaupun program akselerasi dihentikan atau diganti dengan menggunakan sistem SKS, sekolah tetap tidak mempermasalahkan hal tersebut sepanjang program atau sistem yang baru tersebut bisa mengakomodir potensi yang dimiliki peserta didik. Namun, hal ini tidak sesuai dengan kehadiran layanan cerdas istimewa yang secara khusus memang dirancang untuk siswa dengan keunikan tersendiri karena keunggulan kemampuannya, keunggulan CI maupun kecepatan belajar sehingga walaupun hadir misalnya sistem SKS tidaklah tergoyahkan karena layanan CI digunakan untuk layanan khusus. Sistem SKS hanya merupakan sistem sajian kurikulum yang juga ditawarkan dalam layanan CI yang dinamakan dengan grade skipping maupun credit examination. Jauh sebelum sistem SKS muncul pada sekolah telah ada sistem semacam SKS yang dipergunakan dalam layanan CI dan tidak menghilangkan layanan CI itu sendiri. Hakikat grade skipping adalah membolehkan siswa di bawahnya mengikuti kelas di atasnya untuk mata pelajaran tertentu (Van Tassel Baska, 2005 dalam Supriyanto, 2012). Dengan demikian, kehadiran sistem SKS tidak ada pengaruhnya terhadap keberadaan layanan CI.

\section{Evaluasi Product Program Akselerasi SMP Negeri 6 Ambon}

Hasil pencapaian program akselerasi yang telah berjalan di SMP Negeri 6 Ambon sudah cukup memuaskan. Program akselerasi telah meluluskan siswanya 100\% dan alumni program akselerasi diterima di SMA favorit, baik negeri maupun swasta. Namun, hal ini bertolak belakang 
dengan pendapat dari Supriyanto (2012) bahwa pencapaian nilai dalam ujian nasional yang tinggi bagi siswa cerdas istimewa sebenarnya akan tercapai dengan sendirinya, sebab siswa cerdas istimewa yang memiliki IQ tinggi akan terlalu mudah mengerjakan soal ujian yang sejatinya merupakan materi ujian yang bobot dan tingkat kesulitannya jauh di bawah kemampuannya, sebab materi ujian nasional merupakan materi untuk anak normal yang IQ nya sekitar 100 . Dampak program akselerasi untuk masa depan, yaitu: output program mampu bersaing dengan peserta didik dari sekolah lain, ini menunjukkan bahwa ada nilai tambah yang diperoleh sekolah dari program akselerasi tersebut.

\section{SIMPULAN DAN SARAN}

Berdasarkan penelitian yang telah dilakukan mengenai Evaluasi Program Akselerasi di SMP Negeri 6 Ambon, maka dapat disimpulkan bahwa:

1. Pada evaluasi context, penyelenggaraan program akselerasi di SMP Negeri 6 Ambon merupakan inisiatif sekolah sebagai upaya untuk menjawab kebutuhan dan memberikan pelayanan pendidikan kepada peserta didik cerdas istimewa $(I Q \geq 130)$ serta mengefektifkan pemanfaatan sarana dan prasarana sekolah.

2. Penyelenggaraan progran akselerasi di SMP Negeri 6 Ambon dilihat dari input yang meliputi: (a) kebijakan penyelenggaraan program; dan (b) perencanaan program: rekrutmen peserta didik, kurikulum program akselerasi, tenaga pendidik, sarana prasarana, dan pembiayaan, sudah memadai.

3. Dari segi Process, penyelenggaraan program akselerasi di SMP Negeri 6 Ambon telah dilaksanakan sesuai dengan perencanaan program, walaupun masih terdapat beberapa kekurangan dan kendala. Rekrutmen peserta didik sudah dilaksanakan dengan baik, penyesuaian kurikulum hanya akan terlihat pada implementasi dalam KBM, tenaga pendidik (guru) masih ada yang belum memenuhi kualifikasi dan kriteria sebagai pengajar di kelas akselerasi, sarana prasarana belum cukup menunjang kegiatan program akselerasi, dan pembiayaan program yang dirasa masih kurang. Pelaksanaan proses belajar mengajar pada program akselerasi dilaksanakan setiap hari efektif sesuai dengan kalender pendidikan yang disusun oleh sekolah. Adanya hambatan dalam penyelenggaraan program akselerasi terkait dengan kebijakan pemerintah tentang penutupan program akselerasi. 


\section{Jurnal Kelola, Vol. 3, No. 1, Januari-Juni 2016}

4. Product dari penyelenggaraan program akselerasi di SMP Negeri 6 Ambon, yaitu: peserta didik dapat menyelesaikan pendidikannya tepat dua tahun, lulus 100\%, dan diterima di SMA favorit, baik negeri maupun swasta yang berkualitas di Kota Ambon.

Berdasarkan hasil penelitian, maka saran yang dapat diberikan dalam penyelenggaraan program akselerasi di SMP Negeri 6 Ambon, yaitu: sekolah harus lebih intensif melakukan kerja sama dengan pihak lain untuk mendapatkan bantuan dana dalam mendukung penyelenggaraan program, sekolah perlu menyiapkan sarana dan prasarana yang belum dimiliki, dalam hal ini laboratorium bahasa sehingga hal ini tidak lagi menjadi kendala dalam proses pembelajaran di sekolah, dan untuk memberikan pelayanan yang baik kepada peserta didik, maka sekolah juga perlu meningkatkan kualitas guru program akselerasi salah satunya dengan memberikan kesempatan kepada guru untuk studi lanjut S1/S2. Bagi Dinas terkait perlu melakukan monitoring, supervisi, dan evaluasi terhadap penyelenggaraan program akselerasi, khususnya di SMP Negeri 6 Ambon.

\section{DAFTAR PUSTAKA}

Ahmadi, dkk. 2011. Pembelajaran Akselerasi: Analisis Teori dan Praktik serta Pengarubnya Terhadap Mekanisme Pembelajaran dalam Kelas Akselerasi. Jakarta: Prestasi Pustaka.

Argyris, C., \& Schon, D.A. 1978. Organzational Learning: A Theory of Action Perspective. London: Addison Wesley Publishing Company.

Arikunto, Suharsimi dan Safruddin, Cepi A.B,. 2014. Evaluasi Program Pendidikan: Pedoman Toeritis Praktis Bagi Mahasiswa dan Praktisi Pendidikan, Edisi: Kedua. Jakarta: Bumi Aksara.

Arini, Estiastuti. 2008. "Manajemen Pembelajaran Program Akselerasi (Studi Kasus di SD Negeri Sompok Semarang)", Tesis, Semarang: Universitas Negeri Semarang.

Citra Ceria. 2011. "Evaluasi Pelaksanaan Program Akselerasi di SMA Negeri 1 Banjarmasin", Tesis. Universitas Lambung Mangkurat.

Colangelo N, dkk. 2010. "Guidelines for Developing an Academic Acceleration Policy", Journal of Advanced Academics Vol. 21 (2), pp. 180-203.

Colin, R. \& Malcolm, J.N. 1997. Accelerated Learning for the 21st Century; The Six-step Plan to Unlock Your Master Mind. New York: Delacorte Press.

Depdiknas. 2003. Pedoman Penyelenggaraan Program Percepatan Belajar SD, SMP, dan SMA: Suatu Model Pelayanan Pendidikan Bagi Peserta Didik Yang Memiliki Potensi Kecerdasan dan Bakat Istimewa. Jakarta: Balitbang Diknas.

Depdiknas. 2009. Pedoman Penyelenggaraan Pendidikan Untuk Peserta Didik Cerdas Istimewa. Jakarta: Direktorat Jenderal Manajemen Pendidikan Dasar Dan Menengah, Direktorat Pembinaan Sekolah Luar Biasa. 
Direktorat PSLB. 2010. Panduan Guru dan Orang Tua Pendidikan Cerdas Istimewa. Jakarta: Direktorat Jenderal Manajemen Pendidikan Dasar dan Menengah Kementerian Pendidikan Nasional.

Dwi Astutik. 2013. "Evaluasi Program Akselerasi di SMAN 1 Karanganyar Tahun Ajaran 2012/2013", Jurnal Ilmiah Program Studi Sosiologi-Antropologi, Vol. 3, No.1.

Fattah, Nanang. 2008. "Pembiayaan Pendidikan: Landasan Teori dan Studi Empiris". Jurnal, Pendidikan Dasar, No.9.

Haryanto \& Pujiningsih. 2008. "Pelayanan Pendidikan Anak Berbakat Intelektual di Sekolah Dasar”, Prosiding Konaspi VI, Universitas Pendidikan Ganesha

Hawadi, Akbar Reni. 2004. Akselerasi: A-Z Informasi Program Percepatan Belajar. Jakarta: Grasindo.

Ira Mendasari. 2013. "Efektivitas Program Akselerasi (Studi Evaluatif di SMP Negeri 1 Argamakmur)", Tesis. Universitas Bengkulu.

Marland. 1972. Education of The Gifted and Talented. Washington: U.S. Government Printting Office.

Marni Serepinah. 2013. “Kebermaknaan Evaluasi Program Pendidikan”, Jurnal Pendidikan Penabur No. 20, Tahun ke-12.

Meier, Dave. 2000. The Accelerated Learning Handbook: A Creative Guide to Designing and Delivering Faster, More Effective Training Programs. New York: The McGraw-Hill Companies,Inc.

Mujiman, Haris. 2006. Belajar Mandiri. Surakarta: LPP UNS

Mukhtar, dkk. 2007. Pendidikan Anak Bangsa Pendidikan Untuk Semua. Jakarta: Nimas Multima.

Nawawi, H. 1996. Administrasi Pendidikan. Jakarta: Gunung Agung.

Peraturan Pemerintah Nomor 48 Tahun 2008 Tentang Pendanaan Pendidikan.

Permendiknas Nomor 24 Tahun 2007 Tentang Standar Sarana dan Prasarana Untuk Sekolah Dasar/Madrasah Ibtidaiyah (SD/MI), Sekolah Menengah Pertama/Madrasah Tsanawiyah (SMP/MTs), dan Sekolah Menengah Atas/Madrasah Aliyah (SMA/MI).

Rena Putri, Diah Sekar Ayu, dkk. 2005. "Perbedaan Sosialisasi Antara Siswa Kelas Akselerasi dan Kelas Reguler Dalam Lingkungan Pergaulan di Sekolah". Humanitas: Indonesian Psychological Journal Vol. 2 No.1, pp. 28-40.

Semiawan, Conny. 2007. Perspektif Pendidikan Anak Berbakat. Jakarta: Grasindo

Sri Utari. 2014. "Menjadikan Program CI (Cerdas Istimewa) sebagai Program Unggulan di DIY”, http://pendidikandiy.go.id 
Jurnal Kelola, Vol. 3, No. 1, Januari-Juni 2016

Supriyanto, Eko. 2012. Pengembangan Kurikulum Pendidikan Cerdas Istimewa. Yogyakarta: Pustaka Pelajar.

Undang-Undang Republik Indonesia Nomor 20 Tahun 2003 Tentang Sistem Pendidikan Nasional

Ward, V.S. 1980. Differential Education for the Gifted. California: Ventura.

Widiastono, Harry. 2004. "Sistem Percepatan Kelas (Akselerasi) Bagi Siswa yang Memiliki Kemampuan dan kecerdasan Luar Biasa". bttp:/ / www.depdiknas.go.id.

Widoyoko, Eko Putro. 2013. Evaluasi Program Pembelajaran: Panduan Praktis Bagi Pendidik dan Calon Pendidik. Yogyakarta: Pustaka Pelajar

Winanti S, dkk. 2007. "Gambaran Kecerdasan Emosional Siswa Berbakat di Kelas Akselerasi SMA di Jakarta”, Jurnal Psikologi Vol. 5 No. 1, Juni, pp. 30-61.

Wirawan. 2012. Evaluasi: Teori, Model, Standar, Aplikasi, dan Profesi. Jakarta: Rajawali Pers. 